\title{
Scientific Views of the "Dance Macabre" in Treatises of the First Half of the XIX Century
}

\author{
Andrei Sapsuev \\ Department of Music History \\ Krasnoyarsk State Institute of Arts \\ Krasnoyarsk, Russia \\ E-mail: postprintpack@gmail.com
}

\begin{abstract}
The work is devoted to one of the most popular genres of tanatological themes - Dance macabre (Dance of Death). The XIV century witnessed the appearance of images, poetic texts and musical compositions embodying the image of dancing death. However, in the XVII and XVIII centuries, interest in this topic is drying up to be updated in painting, literature and music of the XIX century. At the same time, the first theoretical treatises were also written. But it is this article that for the first time in the Russian musicology draws attention to scientific works of French researchers of the first half of the XIX century dedicated to Dance macabre.
\end{abstract}

Keywords-dance macabre; Dance of Death; the mortal genre; Gabriel Peignot; Eustache Langlois; Jean Kastner; treatise

\section{INTRODUCTION}

For many centuries the theme of death has been embodied in various arts. The first survived images date back to the middle of the 14th century (The Triumph of the Death by Bufalmako), poetic texts date back to the end of the 12th century (The Poems of Death by Monk Elinan), and the first musical composition Ad mortem festinamus (We hasten to meet death) was discovered in the 14th century manuscript the Red Book of Montserrat Monastery. Thoughts about death can be found in the works of philosophers, scientists, churchmen, people of creative professions. It was a key problem of the Middle Ages and was associated with the departure from earthly life and with the salvation of the human soul in the afterlife. One of the popular genres devoted to death was danse macabre -dances of death. Being edifying by nature they made religious people think about death and future afterlife. For a secular man, playing the theatrical performance was akin to a magical ritual, a spell that would protect oneself from imminent danger.

In the XVII-XVIII century, the type of thinking changes because of the change in the picture of the world from the theocentric to the rational one and the development of science and its achievements (scientific discoveries) are aimed at explaining the mystical phenomena that dominate in the Middle Ages. So, the fear of death disappears, and the very theme of death fades into the background to be remembered only in the XIX century, after two centuries of oblivion. The revival of the mortal themes becomes possible due to the aesthetics of Romanticism with its dual perception of the world, which draws its ideals in the Middle Ages; a special neuropsychic, subtle spiritual organization of the artist with his hypersensitivity and openness to mystical and fantastic ideas. It allowed to revive dark scenes with dancing skeletons headed by the Dark figure with a scythe: in literature - W. Goethe (The Dance of Death, 1815), L. Bechstein (Der Totentanz, 1831), P. Lacroix (La Dance Macabre, 1832), Sh. Baudelaire (The Dance of Death, 1857), A. France (The Dance of the Dead, 1868), A. Casalis (The Dance of Death, 1874); in painting - V. Kaulbach (Dance of Death, 4 drawings, 1840's), D. Weber (cemetery chapel in Herten, 1887); in music - F. Liszt (Totentanz (1848), J. Castner (La danse macabre, 1852), K. Saint-Saens (1874), G. Mahler (The Sating Song, 1880-1899).

Numerous artistic incarnations resulted in the comprehension of the mortal genre in the scientific sphere. It is proved by a number of major treatises of both French and British researchers.

This article draws attention to the treatises of French scholars - Les danses des morts et sur l'origine des cartes a jouer (Study of the Dance of Death and the Origin of Playing Cards) by G. Peino (1826), Les danses des morts (Dance of Death) by E.-G. Langlois (1832), Les danses des morts by J.J. Kastner (1852). Though the interest in this genre is increasing throughout the XX century, these works are unknown in the Russian musicology, they have not been translated into Russian yet. Therefore the study of the early scientific treatises is very important and topical, as the scholars consider the history of the rise of dances, etymology, make attempts to explain philosophically the attitude toward death, and analyze works of art.

\section{PERSONALITIES}

First of all, let us turn to some authors of the treatises.

Etienne Gabriel Peignot (May 15, 1767-August 14, 1849) was an attorney but worked as a librarian. He held the post of a book inspector (1813), and a little later the director (1815) of the College Gerome, named after the famous painter and sculptor Jean-Leon Gerome. Peignot was known as the most erudite scholar-bibliographer of the XIX century. The list of his works includes historical, philological, encyclopedic, 
bibliographic publications. All his life he was interested in old books which made him investigate the dances of death.

Eustache-Hyacinth Langlois (August 3, 1777-September 29,1837 ) is a French painter, engraver and sculptor. His life was connected with the city of Rouen, where the artist studied images of local antiquities and attractions, publishing their drawings and engravings in a variety of local publications. Langlois's book Chapel of the Rouen Cathedral is considered to be a contribution into the world history, because its illustrations were the most important source for the restoration of the cathedral after the bombing of the World War II.

Jean-Georges Kastner (March 9, 1810-December 19, 1867) is a French composer and musicologist. He was a versatile personality. His compositional activity began at the age of 16 , and by the time he was twenty-five, the list of his works included a piano concerto, three symphonies, five overtures, a number of works for a brass band, and four operas (for the last opera he was awarded a scholarship to improve his skills in Paris). At the age of 25 Kastner wrote the General Course of Instrumentation, published a year later under the stamp of the Royal Academy of Fine Arts. The textbook was very popular. It should be noted that the famous Treatise on Instrumentation by G. Berlioz was published only seven years later.

Besides, Castner wrote manuals not only on instrumentation, but also on performing various instruments: from timpani to saxophone. His General Guide to Military Music for the French Armies is also known, and the collection of The Songs of the French Army is of particular value thanks to the historical sketch preceding the publication. For twenty years the author kept on working on extensive music dictionary, which unfortunately remained unfinished.

Kastner's theoretical and compositional mastery manifested itself in the genre of the so-called "book-score" (French "livres-partitions"). These are works for choir and orchestra, composed as an appendix to books: literary text and score were published under one cover. Three such books were published by Kastner in co-authorship with Eduard Thierry ${ }^{1:}$ The Dance of Death (Les danses des morts, 1852); Voices of Paris (Les voix de Paris, 1857) - a story about cries and chants of street and market vendors from the Middle Ages to the present; The Musical Paremiology of the French Language (Parémiologie ${ }^{2}$ musicale de la langue française, 1866).

1 Edouard Thierry (September 14, 1813, Paris - November 28, 1894, Paris) - famous French theater and literary man.

2 Paremiology (al-Greek $\pi \alpha \rho \mu_{\mu} \alpha$ í paroimia - parable, proverb and $\lambda$ ó $\gamma$ os logos - word, doctrine) is a subsection of phraseology, a section of philology devoted to the study and classification of paremias - proverbs, antipodes, sayings, vellerisms, slogans, aphorisms, puzzles, and other sayings, the main purpose of which is a short figurative verbal expression of traditional values and views based on the life experience of a group, the people, and so on.

Paremias - special units and signs of language, necessary elements of communication. These signs convey specific information, denote typical life and mental situations or relationships between these or those objects [1].
Kastner was also known as a prominent music critic, who published articles on various issues of musical art.

It is clear that those studying the genre of dance macabre up to the middle of the XIX century were not by no means professional scholars, except for Kastner.

\section{SUBJECT OF RESEARCH IN TREATISES}

Let us try to know the reasons and explain the authors' of scientific works interest in the death dances.

The purpose of Peignot's research is the depiction of death on playing cards, as it is already mentioned in the full title of his treatise Les danses des morts et sur l'origine des cartes a jouer (Study of the Dance of Death and the Origin of Playing Cards). The French librarian dedicates the second part of his work to the extensive research analysis of the image of the Dances on playing cards, where he lists the artists [of playing cards], gives the names of the researchers of this subject, and in the Supplement puts comments on some engravings with a personified death, playing cards and card games [2].

The reasons that made Langlois turn to danse macabre are associated with a particular architectural object. It is known that the first draft treatise on the Dances of the death of the cemetery of Saint-Maclou in Rouen appeared in 1832 in the form of memoirs. Almost all images found in Rouen are recorded and provided with comments. The two-volume edition, prepared by André Poettier and Alfred Baudry ${ }^{3}$ for printing, includes fifty-four scenes and numerous drawings vignettes, drawings, engravings made by the author of the treatise and his daughter Esperance.

A different view of the danse macabre can be found in Kastner's work.

In the first half of the XIX century some works were already devoted to Dances of death, but their authors had not established yet the nature of this strange allegory. In France nobody studied and presented this material in proper form. According to Kastner, most modern writers "even when they flaunt erudition, reproduce in the best way all their errors and mistakes" [3].

The origin and history of the gloomy time of the Middle Ages imprinted their joking signs on the walls of churches, monasteries, graveyards, palaces. These signs are still unsolved mystery, real sacrament for scholars. Kastner tried to clarify the problem in a new way. He was the first to regard dances as "direct descendants" of burial rondes (dances), which were closely connected with dance (choreography) and music. The French musicologist proves that the name of the genre dance, is not used in the meaning of the lesson, morality, or warning, as many scholars believe. It should be interpreted as a term denoting the genre of the poem-allegory with the sound of a musical instrument and a hint of dancing. Jean Kastner proves his point of view on

3 A treatise by Langlois was published thanks to librarian Ruan Andre Pottier and publisher Alfred Baudry. They collected the original essay materials, structured, processed and supplemented them with comments. 
examples taken from texts and drawings of various funeral hymns, explaining the history of their creation (origin), the purpose and philosophical understanding of the monuments studied.

Common features can be found in the structure of treatises. In all three works there are chapters on the history of the development of the genre, while Antiquity is the initial chronological point.

Peignot pays special attention to the chronological period from 1440 to 1524-1526: from the creation of the Basle Dance of Death to the publication of the Holbein's one. There is an opinion that Hans Holbein copied the murals of the walls of the secular cemetery at the Basel Monastery. The French researcher refutes this myth by the example of comparative analysis and comes to the conclusion that the Basle Dance of Death and G. Holbein's Dance of Death are completely different, only the essence of the depicted subject is common in both of them.

In his historical essay Langlois emphasizes the history of Rouen in the 16th century and the cemetery of Saint-Maclou containing images of danse macabre. It should be noted that historical information about the dances is not important for the author, he refers to it while interpreting symbols and attributes decorating the cemetery walls. Langlois does not claim scientific novelty in presenting the facts; on the contrary, he relies on the research of G. Peignot and the English antiquary Francis Douce ${ }^{4}$, who devoted more than thirty years to the study of dance macabre.

A distinctive feature of Kastner's historical excursion is his turning not only to history, but also to philosophy and literature. The last two disciplines allow us to broaden our horizons and trace the implementation of the theme of death in the works of mythologists, philosophers, writers, poets and moralists from ancient times to the middle of the XIX century. Besides, the author of the treatise examines the evolution of the literary text. Kastner gives examples from the most famous fragments of death to the burial rond (des rondes funèbres), as well as a number of works inspired by the philosophy of Memento mori.

While studying dance macabre, Kastner tries to find out what iconographic image is the personification of death. To solve this problem, the scientist turns to ideas about deities creating evil, symbolizing or personifying hostile forces (evil, sin, death) in the main cults (world religions). For Kastner, the perception of the world is the opposing of the deities dwelling under the earth, in the night, in darkness, and the deities living in higher realms, where eternal light dominates - the source of regeneration and life. Here the researcher sees the identity of symbols and the personification of evil deities with the idea of symbols and the personification of Death. The scientist comes to the conclusion that in the art monuments of antiquity the skeleton is not a personification

Francis Hubble Douce (?? 1757 - March 30, 1834). An outstanding member of the Society of Antiquaries of England, from 1799 to 1811 he was the curator of manuscripts in the British Museum. The author of the treatise "The Dance of Death" (published in 1833). According to Langlois, Duse had been studying dance macabre for over thirty years. of this fatal force. In the oldest known Dance of Death the skeleton is rather an evil spirit (larve or larvatus), continuing the embodiment of the antithesis from The Legend of the Three Dead and Three Living, as a special type of iconography of the Christian symbol, a metaphysical individuality called Death. We emphasize that no one had made such statement before Kastner. The scientist gives new reasons that forced artists to imprint a skeleton in playful image, make the character frolic and play instruments to depict the dance. No doubt, they do not explain the phrase dance macabre, its mysterious origin, but they reveal the veil of secrecy. For example, Kastner says that "in ancient times manners were primitive and rude. Often dances were convulsions. The devil was believed to possess a sick person. In the Middle Ages, the sick with plague were forced to dance in the squares. Sometimes special rooms were given for the infected, and during the procession they were accompanied by a musician playing on the horn during day and night, and dancing to music" [4]. It is an evident analogy with the plot of danse macabre.

Thus, there is continuity of views in the presentation of historical information. The authors of the treatises rely on the achievements of their predecessors, supplementing, clarifying, expanding or making their own corrections.

\section{COMPARATIVE ANALYSIS OF TREATISES}

At the same time each treatise is unique in its own way. For example, Peignot, passionately interested in the study of ancient objects, examines and describes art objects that are either directly related to the Dance, or to personified death. Among these works are old books, paintings, engravings. The bibliographer also studies ancient watch books (books about watches), with engraved Danse Macabre along the edges of them.

Eustache-Hyacinth gives interesting and important, in our opinion, descriptions of dance macabre, "performed by living characters (people)" [5], from clerics to simple peasants - a kind of theatrical performances. As a rule, the performers were punished for such dances either by churchmen or by supernatural forces. In the second volume, Langlois analyzes scenes of death dances, illustrating them with graphic images, descriptions, comments.

In the second part of Kastner's treatise the subject of the study is the music of dance macabre. By music, the author means everything that can be correlated with musical art in images, legends, poems, depicting death as a skeleton and people facing it.

The most important component of this part, including 22 chapters, consists of drawings of ancient musical instruments based on a collection of Gothic Doten Dantz, printed in the second half of the 15th century. Copies from wood engravings, reduced (to the same size) and following each other as in the original copy of the Doten Dantz Library of Strasbourg are one of the most interesting monuments of the Dance of Death for the musical art, as it introduces the authentic instrumental ensemble. Here there are both modern instruments and those ones that came out of everyday use, while some instruments are completely unfamiliar. Although 
wood engravings of the Doten Dantz are very rough and imperfect, the instruments are depicted more carefully in comparison with other images which are considered valuable in composition and drawing. Of the forty-one drawings of Doten Dantz, only four skeletons do not play any musical instrument.

Kastner arranged the instruments by kinds and groups (families). This is the subject of a separate chapter, which explains each basic species with a short note on the origin, application, transformation and improvement in different models that appeared both during the formation of the dance macabre genre and later.

Let us list what instruments are being discussed. The winds are represented by the flute, pipe, oboe, bagpipes, horns, trumpets. Portable organs are also described here. Among the strings there are monochords, dichords and trichords, a violin, a wheel lyre, a harp, tympani, lute and guitar. And finally percussion instruments - drums, timpani, bells, xylophone, castanets, triangles.

In fact, the French musicologist and author of the instrumentation textbook wrote an essay on the history of musical instruments of the Middle Ages and the Renaissance.

At the end of his work J. Castner publishes his own score La Danse Macabre with the genre designation Big Rondo with Orchestral Accompaniment. As mentioned above, the poetic text was written ${ }^{5}$ by Eduard Thierry. "I told an outstanding poet about my desire, and, at my request, he began to paraphrase the old Gothic rhymes of the Dance of Death in modern charming poems, alternating with the image of the Death of some main characters of the dance macabre. Focusing on the fragment, our joint intention was to remain faithful to the frame of the funeral poem and contain only those elements that could give the initial information. That is why our work was reduced to the size of the rondo" [6].

After a long and scrupulous study of the genre the French composer offers his own interpretation of the dance of death. "In the music that I composed on Eduard Thierry's elegant poems, I tried to give each character his characteristic sound and appearance either with a special melody or with a special form of accompaniment. My main aim was, especially in chanting, the simplicity of expression that could spread throughout the work with some archaic charm and this mysterious ambiguity, endless melancholy, which we note in most of the works born in the harsh Middle Ages" [6].

The name The Big Rondo is far from being accidental. The oldest funeral dances in their titles contain information about the musical form and choreographic figures - round dances, rondos. In fine arts, the circular motion is imprinted in the form of skeletons' round dances. In literature such a method is manifested in the constant return of one and the same line or phrase. The musical composition of the French composer also has a similar structure: a rondo consisting of thirteen episodes, in which the replicas of Death serve as a refrain ( 7 episodes), the remaining six belong to the characters of different classes (from the king to a baby). The idea of a closed circle also manifests itself at the macro level The first stanza belongs to the holiday leader and contains an invitation to dance:

My sons, join your hands;

Form a huge circle (big round dance),

It's me, I'm Death and I'm giving a ball!

The final phrase also sounds from the mouth of Death and indicates the inevitability of the action:

On the spot, it's time to start.

No answer, you must dance!

\section{CONCLUSION}

The interest in dance macabre in the era of Romanticism continues in the XX-XXI century. It is proved by numerous works in this genre from classical and contemporary pop music, literary compositions to the same movies and performances. In the scientific realm, a new wave of genre begins: different hypotheses about the origin of the Danse Macabre are being developed, the etymology of the strange definition of "macabre" is being studied. It is reflected in the Notes sur la Danse Macabre by French musicologist Armand Machabe, separate chapters of the books Sin and Fear: Forming a Sense of Guilt in the Western Civilization of the (13th-18th centuries), Identification of Horror by French historian Jean Delumo, Autumn of the Middle Ages by Dutch cultural scientist Johan Huizinga, the Soviet musicologist and art critic I. Ioffe's reflections in Mysteries and Opera (German Art of the 16th-18th centuries).

New methods and approaches are also being formed. One of the possible ways to study danse macabre is the reference to the authentic documents. The need in their search, translation and interpretation makes us take a closer look at the way the contemporaries themselves examined this problem in various aspects, for example, religious, mythological, philosophical, creative, etc.

\section{REFERENCES}

[1] https://ru.wikipedia.org/wiki/Paremiology

[2] G. Peignot. Research on the dance of the dead and the origin of playing cards. - Paris, 1826. - P. 199-325. (in Franch).

[3] J.-G. Kastner. The dances of the dead: dissertations and historical, philosophical, literary and musical research on the various monuments of this kind that exist or have existed both in France and abroad - Paris, 1852. - P. VIII.(in Franch).

[4] J.-G. Kastner. The dances of the dead: dissertations and historical, philosophical, literary and musical research on the various monuments of this kind that exist or have existed both in France and abroad - Paris, 1852. - P. 62. (in Franch)

[5] E.-H. Langlois. Historical, philosophical and picturesque essay on the dances of the dead. - Rouen, 1852. - T. I, p. 164-177.(in Franch).

[6] J.-G. Kastner. The dances of the dead: dissertations and historical, philosophical, literary and musical research on the various monuments of this kind that exist or have existed both in France and abroad - Paris, 1852. - P. XV.(in Franch). 